\title{
COVID-19 Risk Perception, Knowledge, Precautions and Information Sources between Healthcare Professionals
}

\author{
Sağlık Profesyonelleri Arasında COVID-19 Risk Algısı, Bilgisi, Önlemleri ve Bilgi Kaynakları Analizi
}

\section{Necip Gokhan Guner ${ }^{1}$, iD Yusuf Yurumez ${ }^{2}$, iD Fatih Guneysu', iD Bilge Ercan', iD Volkan Ulker $^{1}$}

1-Sakarya University Training and Research Hospital, Clinic of Emergency Medicine, Sakarya, Turkey. 2-Sakarya University Faculty of Medicine, Department of Emergency Medicine, Sakarya, Turkey.

\begin{abstract}
Objective: Healthcare professionals are one of the groups at highest risk of transmission, as they are in close contact with COVID-19 patients. Naturally, people who see themselves at risk for COVID-19 may be worried. This study aims to determine perceptions, knowledge levels, measures, and resources of healthcare professionals and make additional suggestions.

Material and Method: This cross-sectional study was conducted from the 10th to 17th of March, 2020. Participants were assessed using an online questionnaire containing risk perceptions, knowledge, preventive behaviors, and sources of information about COVID-19. The questionnaire was created from 4 chapters and 61 questions. The data obtained were analyzed with IBM SPSS 21.

Results: A total of 305 healthcare professionals completed the questionnaire. The median age of participants was 26 years (IQR: 23-30). The highest Perceived vulnerability risk score belongs to cold. (mean: 3.8; SD: 0.9) However, the highest Perceived severity score belongs to COVID-19 (mean: 6.5; SD: 2.6). A mean knowledge score of 3.3 (standard deviation $[S D]=0.6$ ) was observed; $87.5 \%$ of the respondents answered three or more knowledge questions correctly. It has been determined that the most preferred method of protection is to washing hands more frequently (82.6\%). Conclusion: The results indicate that the healthcare professionals were well aware of the COVID-19 outbreak, knew what COVID-19 was, about their risk, and obtained their information primarily from the internet and doctors, which were also rated as trustworthy sources of information.
\end{abstract}

\section{ÖZET}

Amaç: Sağllk uzmanlarl, COVID-19 hastalarıyla yakın temas halinde olduklarl için bulaşma riski en yüksek gruplardan biridir. Doğal olarak, kendilerini COVID-19 için risk altında gören insanlar endişeli olabilir. Bu çalı̧manın amact, sağllk mesleği mensuplarının algılarını, bilgi düzeylerini, ölçütlerini ve kaynaklarını belirlemek ve ek önerilerde bulunmaktrr.

Gereç ve Yöntem: Bu kesitsel çalışma 10 - 17 Mart 2020 tarihleri arasında gerçekleştirildi. Katıllmcılar, COVID-19 ile ilgili risk algıları, bilgiler, önleyici davranışlar ve bilgi kaynaklarını içeren çevrimiçi bir anket kullanılarak değerlendirildi. Anket 4 bölüm ve 61 sorudan oluşturuldu. Elde edilen veriler IBM SPSS 21 ile analiz edildi.

Bulgular: Toplam 305 sağlık çalışanı anketi tamamladı. Katılımcıların medyan yaşı 26 idi (IQR: 23-30). Algılanan en yüksek güvenlik açığı riski puanı soğuğa aittir (ortalama: 3,8; SS: 0,9). Bununla birlikte, Algılanan en yüksek şiddet puanı COVID-19'a aittir (ortalama: 6.5; SS: 2.6). 3.3'lük bir ortalama bilgi puanı (standart sapma [SS] $=0.6$ ) gözlemlendi; Katılımcıların \%87,5'i üç veya daha fazla bilgi sorusunu doğru cevapladı. En çok tercih edilen korunma yönteminin elleri daha sık yıkamak $(\% 82,6)$ olduğu belirlenmiştir.

Sonuç: Sağllk çalışanlarının COVID-19 salgını konusunda yeterli bilgi sahibi oldukları, COVID-19'un ne olduğunu, riskleri hakkında bilgi sahibi olduklarını ve bilgilerini öncelikle internetten ve aynı zamanda güvenilir bilgi kaynakları olarak değerlendirilen doktorlardan elde ettiklerini göstermektedir.
Keywords:

COVID-19,

Healthcare providers,

Knowledge,

Prevention and control,

Risk

Anahtar Kelimeler: COVID-19,

Sağlık sağlayıcıları, Bilgi,

Korunma ve kontrol, Risk

\section{INTRODUCTION}

The novel coronavirus (SARS-CoV-2) is first identified in Wuhan, China in December 2019. SARS-CoV-2 is from the coronavirus family, and scientists said that a mutation within the virus that enables human-to-human transmission occurred, and such a pandemic could result in millions of deaths worldwide. Over 18 million people have been infected so far, and more than 600 thousand people have died from Coronavirus Disease 2019 (COVID-19) (1). So there was a panic situation all over the world and the World
Health Organization (WHO) raised the global risk of COVID-19 to the highest level on February 28 (2). In Protection Motivation Theory, the public's tendency to take protective measures is affected by the perceived high-risk levels. Protection Motivation Theory suggests that the public's perception of the severity and vulnerability of a health threat determines the risk perception of a disease (3). Also, people who see themselves at risk for COVID-19 may be anxious, but may also stigmatize those who are perceived as possible sources of infection (4).

Received: 09.02.2021 
To promote realistic risk perceptions and effective precautions, communication through various information sources is essential (5). Aware of this fact, organizations like WHO have influenced people's risk perceptions and protection behaviors by providing various information and suggestions. For example; the WHO stated that COVID-19 is a new disease, but it should be recognized that outbreaks can be managed with the right answer, and the vast majority of infected people will recover. Also, although they often recommend handwashing, people were asked to constantly update their knowledge about COVID-19 and its signs and symptoms (i.e. fever and dry cough). Finally, the WHO suggested that people change their lifestyles, adopt stricter 'social distance' practices and help older people with a higher risk group (1).

Since healthcare professionals are in close contact with the affected people, they are always at risk of infectious disease. In a study, the rate of transmission to healthcare professionals was $29 \%$. As with all people, the behavior of healthcare professionals has been affected by this outbreak. Also, incomplete information of this population can affect the appropriateness of medical decisions by increasing the perception of risk, increasing stress and anxiety levels (6). This study aims to determine the perception of healthcare professionals, their level of knowledge, precautions, and sources of information, and to provide additional suggestions.

\section{MATERIAL AND METHOD}

The Study design: To investigate the use of risk perceptions, information, actions, and information sources about COVID-19 between healthcare professionals, permission was obtained from the Sakarya University School of Medi-cine ethics committee before starting the study (Decision no: 04/04/2020-E.3948). The questionnaire: This cross-sectional study was carried out electronically with the participation of 305 healthcare professionals between 10-17 March 2020. The data were collected with the COVID-19 questionnaire prepared based on the questionnaire used in a study on severe acute respiratory syndrome (SARS) (7).

The questionnaire was created from 4 chapters and 61 issues. The questionnaire contained questions about information sources and health and efficacy beliefs regarding COVID-19; it causes serious illness and spreads easily in the population. Questions covered the following aspects: sociodemographic background; the amount of information about emerging infectious diseases the respondent got in the past year from a range of different sources of information ("How much information about emerging diseases did you get from the following sources in the past year: none, little, some, much, very much"); the confidence he/she had in this information ("How much confidence did you have in information about emerging diseases you got from these sources in the past year: none, little, some, much, very much"); COVID-19 knowledge ("Can you select the most important symptom of COVID-19"; "COVID-19 is a communicable disease, COVID-19 can be infected without symptoms, COVID-19 agent is a zoonotic: true, false, don't know"); Each question in the knowledge level section was accepted as 1 point and evaluated over 0-4 points. Perceived severity ("On a scale from 1 to 10 , how serious would it be for you to get the following diseases in the next year"); perceived vulnerability ("How likely do you think it is for you to get the following diseases in the next year: very unlikely, unlikely, not unlikely/not likely, likely, very likely"); response efficacy ("In general, do you think that people in Turkey can take actions to prevent getting the following diseases: not at all, a little bit, quite a bit, definitely"); and self-efficacy ("How confident are you that you can prevent getting the following diseases: not confident, somewhat confident, quite confident, very confident") (7). The internal consistency coefficients were 0.86 (Cronbach's $\alpha$ ) for the perceived vulnerability and perceived severity. Statistical Analysis: Data from respondents were compared using Student's t-test or the Mann-Whitney test was used for comparison of continuous endpoints, and the $\chi^{2}$ or Fisher's exact test was used for comparison of endpoints expressed as percentages. All tests were done with a two-sided significance of 5\%. For each endpoint, the absolute and relative effects and their corresponding 95\% CIs were calculated as recommended by Altman and colleagues. Because of indicated we use for Spearman's rho correlations. All analyzes were performed in SPSS 21.

Table 1: Demographic data about the volunteers

\begin{tabular}{|c|c|c|}
\hline & & Median (IQR) \\
\hline Age (Years) & & $26(23-30)$ \\
\hline $\begin{array}{l}\text { Household } \\
\text { Members } \\
\text { (Number; } \\
\text { Median) }\end{array}$ & & $3(2-4)$ \\
\hline & & n (\%) \\
\hline \multirow{2}{*}{ Gender } & Male & $122(40)$ \\
\hline & Female & $183(60)$ \\
\hline \multirow{3}{*}{$\begin{array}{l}\text { Place of } \\
\text { Residence }\end{array}$} & City & 258 (84.6) \\
\hline & Town & $34(11.1)$ \\
\hline & Village/countryside & $13(4.3)$ \\
\hline \multirow{3}{*}{$\begin{array}{l}\text { Highest } \\
\text { Education }\end{array}$} & High school & $110(36.1)$ \\
\hline & University & $120(39.3)$ \\
\hline & Postgraduate & $75(24.6)$ \\
\hline \multirow{3}{*}{ Job } & Medical Doctor & $124(40.7)$ \\
\hline & Nurse & $74(24.2)$ \\
\hline & Medical Student & $107(35.1)$ \\
\hline
\end{tabular}




\section{RESULTS}

305 volunteers randomly selected were included in the study. Demographic data about the volunteers are shown in table 1.

To compare the COVID-19 related risk perceptions to other potential threats, respondents were asked to indicate how likely they thought it was for them to get other diseases or have accidents. A high percentage of respondents think they will more likely get colds $(93.1 \%)$, flu from a new flu virus (83.3\%), and COVID-19 (68\%) diseases in the next year (Table 2). The disease that the participants were worried about the most was determined as COVID-19 disease according to the perceived severity scale (mean: 6.5; SD: 2.6)

Knowledge of COVID-19 was very high among healthcare professionals in Turkey. Everyone involved in the survey knew that the disease was contagious $(100 \%)$. Also, the vast majority knew that the disease was infectious at the time when the disease was asymptomatic (92\%). The number of people who knew that the most common symptom of the disease was fever $(65 \%)$ and that the factor was zoonotic (71\%) was relatively few. A mean knowledge score of 3.3 (standard deviation $[\mathrm{SD}]=0.6$ ) was observed; $87.5 \%$ of the respondents answered three or more knowledge questions correctly.

Response efficacy, i.e., the extent to which respondents think that people generally can take effective actions to prevent disease, COVID-19 was found to have the highest response efficacy score. Also Self-efficacy, i.e. the extent to which respondents think they can prevent disease, The self-efficacy score was detected in the highest cold (Table 3).

Respondents were asked how much information about emerging diseases they got in the past year from a list of sources of information. While it was seen that the information was obtained mostly from the internet, it was determined that the most trusted information was the information received from the doctor (Table 4). When the participants were asked about their preferred three methods to prevent infection, it was found that the most preferred method was to increase the frequency of handwashing $(82.6 \%)$. While avoiding public transportation is in the second place (59\%), avoiding going to the doctor was in the third-place unless there are findings of flu (41\%) (Table 5).

Spearman's rho correlations indicated that perceived vulnerability score was positively associated with perceived severity score risk and age, while negative associations were found with self-efficacy score. Perceived severity score was further associated with age and negative associated with response efficacy score. On the other hand response, efficacy score was associated negatively with age. Finally, the self-efficacy score was positively associated with the number of people living while a negative association was found with age (Table 6).

Table 2: The perceived vulnerability risk score of being affected by COVID-19 and other diseases or accident and perceived severity score

\begin{tabular}{|c|c|c|c|c|}
\hline & & $\begin{array}{c}\text { Perceived } \\
\text { vulnerability risk } \\
\text { score mean (SD)* }\end{array}$ & $\begin{array}{l}\text { \% likely or } \\
\text { very likely }\end{array}$ & $\begin{array}{c}\text { Perceived } \\
\text { severity score } \\
\text { mean (SD) }\end{array}$ \\
\hline COVID-19 & & $3.8(0.9)$ & $68 \%$ & $6.5(2.6)$ \\
\hline \multirow{10}{*}{$\begin{array}{l}\text { Other diseases or } \\
\text { accident }\end{array}$} & Diabetes mellitus & $2.2(1.2)$ & 18.4 & $3.2(2.6)$ \\
\hline & Cold & $4.4(0.6)$ & 93.1 & $4.9(3.2)$ \\
\hline & HIV/AIDS & $1.9(1.0)$ & 11.2 & $3.7(3.3)$ \\
\hline & Hypertension & $2.3(1.1)$ & 20.3 & $3.4(3.0)$ \\
\hline & Tuberculosis & $2.5(1.1)$ & 22.6 & $4.1(2.9)$ \\
\hline & Food poisoning & $3.5(0.8)$ & 63.6 & $4.1(2.4)$ \\
\hline & Flu from a new flu virus & $3.9(0.8)$ & 83.3 & $4.9(2.8)$ \\
\hline & Accident at home & $3.6(0.9)$ & 66.5 & $4.5(2.6)$ \\
\hline & Traffic accident & $3.5(0.8)$ & 63.3 & $5.4(2.7)$ \\
\hline & Heart attack & $2.7(1.0)$ & 28.5 & $4.4(3.1)$ \\
\hline
\end{tabular}

$* 1=$ very unlikely and $5=$ very likely for perceived vulnerability 
Table 3: Mean scores (SD) of response and self-efficacy (both scale 1-4) regarding COVID-19, Cold, and flu from a new flu virüs

\begin{tabular}{|l|l|c|}
\hline \multicolumn{2}{|l|}{} & Mean (SD) \\
\hline \multirow{4}{*}{ Response efficacy } & COVID-19 & $\mathbf{2 . 7 ( 0 . 7 )}$ \\
\cline { 2 - 3 } & Flu from a new flu virüs & $1.9(0.6)$ \\
\cline { 2 - 3 } Self-efficacy & Cold & $1.8(0.7)$ \\
\hline & COVID-19 & $1.9(0.7)$ \\
\cline { 2 - 3 } & Flu from a new flu virüs & $1.9(0.7)$ \\
\cline { 2 - 3 } & Cold & $\mathbf{2 . 0}(\mathbf{0 . 7})$ \\
\hline
\end{tabular}

Table 4: Mean scores* of the amount of information regarding emerging infectious diseases received from different information sources and confidence in the information among healthcare professionals

\begin{tabular}{|l|c|c|}
\hline & $\begin{array}{c}\text { Amount of information, mean } \\
\mathbf{( \% 9 5} \mathbf{~ C I )}\end{array}$ & $\begin{array}{c}\text { Confidence in the information means } \\
\mathbf{( \% 9 5 ~ C I )}\end{array}$ \\
\hline Newspaper & $1.8(1.7-1.9)$ & $1.8(1.7-1.9)$ \\
\hline Television & $3.0(2.9-3.1)$ & $2.4(2.3-2.5)$ \\
\hline Radio & $1.6(1.5-1.7)$ & $1.7(1.6-1.8)$ \\
\hline Internet & $\mathbf{4 . 4}(\mathbf{4 . 3 - 4 . 5 )}$ & $3.1(3.0-3.2)$ \\
\hline Doctor & $\mathbf{3 . 6}(\mathbf{3 . 4 - 3 . 7 )}$ & $\mathbf{4 . 0}(\mathbf{3 . 9}-\mathbf{4 . 1})$ \\
\hline Government agencies & $3.0(2.9-3.1)$ & $\mathbf{3 . 2} \mathbf{( 3 . 0 - 3 . 3 )}$ \\
\hline Associations & $1.9(1.7-2.0)$ & $1.9(1.7-2.0)$ \\
\hline Family or friends & $3.0(2.9-3.1)$ & $3.0(2.9-3.1)$ \\
\hline
\end{tabular}

*Scale ranged from 1 = very little to $5=$ very much. CI, confidence interval.

Table 5: The proportion of respondents who reported specific actions to prevent COVID-19

\begin{tabular}{|l|c|}
\hline Precautionary action & Percentage \\
\hline Avoid public transport & $\mathbf{5 9 . 0 \%}$ \\
\hline Avoid going out for entertainment, such as bars, restaurants, theatres, cinema & $\mathbf{3 9 . 3 \%}$ \\
\hline Limit shopping to the Essentials & $11.1 \%$ \\
\hline Take absence from work & $7.9 \%$ \\
\hline Keep the children out of school (even if the school is still open) & $10.5 \%$ \\
\hline Limit physical contact with friends and family & $17.0 \%$ \\
\hline Avoid seeing doctors, even when you're sick from something unrelated to the flu & $41.0 \%$ \\
\hline Stay indoors at all times & $14.1 \%$ \\
\hline Wore a mask & $16.4 \%$ \\
\hline Washed hands more often & $\mathbf{8 2 . 6 \%}$ \\
\hline Exercised regularly & $1.6 \%$ \\
\hline
\end{tabular}


Table 6: Spearman's rho correlations between COVID-19 related risk perceptions, knowledge, efficacy scores, and sociodemographic

\begin{tabular}{|l|c|c|c|c|c|c|}
\hline & 1 & 2 & 3 & 4 & 5 & 6 \\
\hline 1. COVID-19 Vulnerability Risk Score & & & & & & \\
\hline 2. COVID-19 Perceived Severity Score & $\mathbf{0 . 4 4}$ & & & & & \\
\hline 3. Knowledge Score & 0.06 & 0.01 & & & & \\
\hline 4. Response Efficacy Score & -0.01 & $\mathbf{- 0 . 1 6}$ & -0.10 & & & \\
\hline 5. Self Efficacy Score & $\mathbf{- 0 . 2 1}$ & -0.10 & -0.06 & $\mathbf{0 . 1 4}^{\mathbf{c}}$ & & \\
\hline 6. Age & $\mathbf{0 . 1 7}$ & $0.12^{\mathbf{c}}$ & 0.04 & $\mathbf{- 0 . 1 9}$ & $\mathbf{- 0 . 2 5}^{\mathbf{a}}$ & \\
\hline 7. Number Of People Living At Home & -0.05 & -0.05 & -0.04 & 0.01 & $\mathbf{0 . 1 9}^{\mathbf{b}}$ & -0.78 \\
\hline
\end{tabular}

${ }^{\mathrm{a}} \mathrm{p}<0.001{ }^{\mathrm{b}} \mathrm{p}<0.01^{\mathrm{c}} \mathrm{p}<0.05$

\section{DISCUSSION}

COVID-19 disease can affect all age groups. However, it is said that the most affected group is middle-aged and older adults and the clinic is more severe in older adults. (8) On the other hand, the fact that this study was made for an audience consisting of young people rather than the old population adds a different feature to the study. The average age of the participants in this study is 26 . The second feature of this study is that since there is not enough literature about the COVID-19 outbreak, some parameters of this study are compared with previous studies on SARS and Middle East Respiratory Syndrome (MERS).

COVID-19 is a disease of zoonotic origin that can be transmitted from person to person, manifesting itself with the most common complaints such as fever and cough (9). It is extremely important to recognize the disease in the early period. In our study, the average score obtained from the correct answers given by the participants to the questions asked to evaluate the level of knowledge was $82 \%$. When we look at the literature on this subject, we see that there are similar results. Indeed, in a similar study by Taghrir et al., the average of correct answers was found to be $87 \%$. (10). In previous studies about MERS, the level of knowledge was found to be lower $(6,11)$. These results show that people know what is important about COVID-19. Although the participants in our study thought they would be affected by the most common cold next year, COVID-19 ranked first as the most worrying disease. Indeed, when studies on this subject are examined, it is seen that there is a similar picture and people think that they will affect the most common colds. In a study on SARS, Voeten, et al. found that participants' perceptions of the risk of SARS are lower than other factors, and the probabil-ity of getting flu from a new flu virus creates a higher risk perception. However, when their perceptions about the severity of the disease were examined, it was revealed that they thought that SARS would have more severe (7). Zwart et al. the results of another study conducted by supports these results. In this context, our study results are compatible with the literature (12).

Self-efficacy and response efficacy beliefs are a condition affected by the pandemics, cultural structures, and precautions (13). Also, according to the self-efficacy theory, the factors affecting the behavior are based on the belief that the person can perform this behavior (14). The volunteers who participated in our study think that selfefficacy is less than response efficacy to be protected from COVID-19. Similar results were found in a study by Voerten et al. (7). When the literature is examined, it is seen that television is among the most preferred sources to learn the diseases that emerged among the participants last year. Contrary to these results, the most preferred resource in our study is the internet. We think that this difference arises from the fact that the studies were carried out in different periods and the internet is not used as widely as today. In the evaluation of news sources in terms of trust, Brug et al., Voeten et al., and our study results are similar $(7,15)$. In all three studies, it was revealed that the most reliable source of information is doctors. The most reliable source after doctors were state institutions in our study.

There can be many methods to prevent the disease. However, what is important here is which one is more preferred. The most preferred methods in our study are hand washing, avoiding public transportation, and not going to entertainment venues, respectively. When the studies on this subject are analyzed, hand washing was reported as the most preferred method in the study conducted by Rubin et al. In contrast, Taghrir et al. .n a study carried out by, avoiding crowded environments was found to be the most preferred method $(10,16)$. Brug et al. studied the same subject at 
SARS and found not to travel to infected areas as the most preferred method of protection (15). These different results are probably because the studies were carried out at different places and times.

In our study, we found a positive correlation between the COVID-19 vulnerability risk score and the perceived severity score. Brug et al. conducted a similar study on SARS and found a similar correlation (15). This means that as the vulnerability risk score for COVID-19 increases, there is an increase in the perception that the disease will be more severe. On the other hand, in our study, a negative correlation was found between the selfefficacy score and the COVID-19 vulnerability risk score. It is an expected result that people think they are less likely to get COVID-19 when they find the measures sufficient. A similar result was found in Taghrir et al.'s study on COVID-19. A negative correlation was also reported in this study. However, Rubin et al. found a different result in their study on swine flu. This finding is in contrast to the results of the study conducted by Rubin et al. in which the two variables were concordant. The study of Taghrir et al. and our study were done among healthcare professionals, and the participants dominated the results of personal infectious preventive behavior. However, in a study by Rubin et al. participants were sampled from the general population and higher risk perception was associated with higher levels of preventive behavior. Therefore, different results can be reasonable $(10,16)$. Also, a positive correlation was found between the COVID-19 vulnerability score and age in our study. And, as age increased, self-efficacy and response efficacy scores decreased. This means that with advanced age, people see the possibility of getting the disease more likely. However, as age increases, it is understood that they find their precautions and community measures insufficient to prevent disease. Indeed, The WHO report also states that the disease may have more serious consequences for the elderly (1).

In conclusion, the results indicate that the healthcare professionals were well aware of the COVID-19 outbreak, knew what COVID-19 was, about their risk, and obtained their information primarily from the internet and doctors, which were also rated as trustworthy sources of information. However, this study because it is the first study published related to COVID-19 from Turkey, which reported on the public perception must be supported by additional studies.

Limitations: We believe that this study is limited since there is no standardized scale for COVID-19 risk perception, knowledge level, and behavioral evaluation.

Conflict of Interest: No conflict of interest was declared by the authors.

\section{REFERENCES}

1. WHO. Coronavirus disease. World Heal Organ [Internet]. 2020;2019:2633. Available from: https://www.who.int/emergencies/diseases/novel-coronavirus-2019.

2. WHO. WHO Director-General's opening remarks at the media briefing on COVID-19. World Heal Organ [Internet]. 2020;(February):5-8. Available from: https://www.who.int/dg/speeches/detail/who-director-general-s-opening-remarks-at-the-media-briefing-on-covid-19---11-march-2020.

3. Rogers RW. A Protection Motivation Theory of Fear Appeals and Attitude Change1. J Psychol. 1975;91(1):93-114.

4. Eiser JR. Communication and interpretation of risk. Br Med Bull. 1998;54(4):779-790.

5. Fischhoff B. Risk Perception and Communication. Annu Rev Public Health. 1993;14(1):183-203.

6. Kim JS, Choi JS. Middle East respiratory syndrome-related knowledge, preventive behaviours and risk perception among nursing students during outbreak. J Clin Nurs. 2016;25(17-18):2542-2549.

7. Voeten HA, de Zwart O, Veldhuijzen IK, Yuen C, Jiang X, Elam G, et al. Sources of information and health beliefs related to SARS and avian influenza among Chinese Communities in the United Kingdom and the Netherlands, compared to the general population in these countries. Int J Behav Med. 2009;16(1):49-57.

8. Sah R, Rodriguez-Morales AJ, Jha R, Chu DKW, Gu H, Peiris M, et al. Complete Genome Sequence of a 2019 Novel Coronavirus (SARS-CoV-2) Strain Isolated in Nepal. Microbiol Resour Announc. 2020;12;9(11):e00169-20. DOI: 10.1128/MRA.00169-20.

9. Lai CC, Liu YH, Wang CY, Wang YH, Hsueh SC, Yen MY, et al. Asymptomatic carrier state, acute respiratory disease, and pneumonia due to severe acute respiratory syndrome coronavirus 2 (SARS-CoV-2): Facts and myths. J Microbiol Immunol Infect. 2020;53(3):404-412. DOI: 10.1016/j.jmii.2020.02.012.

10. Taghrir MH, Borazjani R, Shiraly R. COVID-19 and Iranian Medical Students; A Survey on Their Related-Knowledge, Preventive Behaviors and Risk Perception. Arch Iran Med [Internet]. 2020;23(4):249-254. DOI: 10.34172/aim.2020.06.

11. Khan MU, Shah S, Ahmad A, Fatokun O. Knowledge and attitude of healthcare workers about middle east respiratory syndrome in multispecialty hospitals of Qassim, Saudi Arabia. BMC Public Health. 2014;14(1):1-7.

12. De Zwart O, Veldhuijzen IK, Elam G, Aro AR, Abraham T, Bishop GD, et al. Perceived threat, risk perception, and efficacy beliefs related to SARS and other (emerging) infectious diseases: Results of an international survey. Int J Behav Med. 2009;16(1):30-40.

13. Chang EC, Asakawa K. Cultural Variations on Optimistic and Pessimistic Bias for Self Versus a Sibling: Is There Evidence for Self-Enhancement in the West and for Self-Criticism in the East When the Referent Group is Specified? J Pers Soc Psychol. 2003;84(3):569-581.

14. Bandura A. Self-efficacy: The exercise of control. New York: W.H. Freeman; 1997.

15. Brug J, Aro AR, Oenema A, De Zwart O, Richardus JH, Bishop GD. SARS risk perception, knowledge, precautions, and information sources, the Netherlands. Emerg Infect Dis. 2004;10(8):1486-1489.

16. Rubin GJ, Amlôt R, Page L, Wessely S. Public perceptions, anxiety, and behaviour change in relation to the swine flu outbreak: Cross sectional telephone survey. BMJ. 2009;339(7713):156. 